\title{
PENGEMBANGAN ASAS-ASAS UMUM PEMERINTAHAN YANG BAIK MELALUI LOCAL WISDOM KERATON YOGYAKARTA
}

\author{
Eny Kusdarini, Sunarso, dan Setiati Widihastuti \\ Fakultas Ilmu Sosial Universitas Negeri Yogyakarta \\ email: eny_kusdarini@uny.ac.id
}

\begin{abstract}
Abstrak: Pengembangan Asas-Asas Umum Pemerintahan yang Baik melalui Local Wisdom Keraton Yogyakarta. Penelitian ini bertujuan untuk mendeskripsikan nilai-nilai kearifan lokal (local wisdom) Keraton Yogyakarta yang merupakan ajaran-ajaran karakter yang baik bagi seorang pemimpin untuk melindungi masyarakat yang dipimpinnya. Nilainilai kearifan lokal ini bisa dipakai untuk mengembangkan asas-asas umum pemerintahan yang baik terutama pada pemerintahan daerah yang ada di Daerah Istimewa Yogyakarta. Penelitian ini adalah penelitian hukum dengan pendekatan yuridis dan budaya. Pengumpulan data dilakukan dengan teknik wawancara dan dokumentasi. Analisis data dilakukan dengan tahap-tahap reduksi data, unitisasi/kategorisasi data dan penafsiran data. Hasil Penelitian menunjukkan bahwa banyak nilai kearifan lokal Keraton Yogyakarta dan nilai-nilai lokal masyarakat Jawa yang merupakan nilai-nilai etik yang bisa dipakai untuk mengembangkan asas-asas pemerintahan yang baik di Daerah Istimewa Yogyakarta. Di antara nilai kearifan lokal tersebut adalah nilai Hamemayu Hayuning Bawana, Sawiji Greget Sengguh Ora Mingkuh, dan Golong-gilig serta nilai-nilai kearifan lokal lainnya. Di samping itu juga ada nilai-nilai etik yang berasal dari ajaran Ki Hajar Dewantoro tentang kepemimpinan yang baik, yakni ing ngarsa sung tuladha, ing madya mangun karsa, dan tut wuri handayani.
\end{abstract}

Kata kunci: local wisdom, Keraton Yogyakarta, pengembangan asas-asas umum pemerintahan yang baik

\begin{abstract}
Developing Good Governance Principles using Yogyakarta Palace Local Wisdom. This study was aimed at describing the values of Yogyakarta palace local wisdom which teach good characters for a leader to protect the people they lead. The values of the local wisdom can be used to develop general principles of good governance, especially in Yogyakarta local government. This research is a law with juridical and cultural approach. The data were collected through interview and documentation. In addition, the data analysis was performed with data reduction stages, unitization/categorization of data and interpretation of data. The result shows that many values contained in Yogyakarta palace and community local wisdom which are the Javanese ethical values that can be used to develop the principles of good governance in Yogyakarta. Among these are the value of Hamemayu Hayuning Bawana, Sawiji Greget Sengguh Ora Mingkuh, and Golong-gilig and others. Besides, there are ethical values derived from Ki Hajar Dewantoro related to good leadership, which is ing ngarsa sung tuladha, ing madya mangun karsa, and tut wuri handayani.
\end{abstract}

Keywords: local wisdom, Yogyakarta Palace, good government principle 


\section{PENDAHULUAN}

Asas-asas umum pemerintahan yang baik awalnya merupakan bagian dari hukum yang tidak tertulis dan merupakan nilai-nilai etik yang harus dipatuhi oleh para penyelenggara negara baik di pusat maupun di daerah. Asasasas itu berasal dari nilai-nilai etik yang berkembang di dalam masyarakat dan sebetulnya telah sejak lama dipraktikkan oleh masyarakat setempat. Oleh karena itu, dapat dikatakan bahwa nilai-nilai itu dikembangkan berdasarkan kearifan lokal (local wisdom) dan berkembang dalam masyarakat. Nilai-nilai kearifan lokal yang berkembang di dalam masyarakat ini bisa dikembangkan menjadi asas-asas umum dalam pemerintahan yang dapat dipakai sebagai patokan dan pedoman bagi alat administrasi negara atau alat birokrasi dalam menjalankan tugas dan kewenangannya agar tidak merugikan warga masyarakat.

Daerah Istimewa Yogyakarta (DIY) merupakan salah satu provinsi di Indonesia yang sebagian besar warganya adalah keturunan suku Jawa, yang sarat dengan nilai-nilai kearifan lokal dan telah dijalankan sejak lama oleh masyarakatnya. Di DIY ada Keraton Yogya yang sampai saat ini keberadaannya masih eksis. Dari Keraton Yogyakarta banyak nilai kearifan lokal yang dapat dipakai untuk mengembangkan asas-asas umum pemerintahan yang baik, walaupun nilainilai itu sebetulnya ada juga yang berasal dari masyarakat Jawa. Contoh nilai-nilai kearifan lokal Keraton Yogyakarta yang bisa dijadikan untuk pengembangan asasasas umum pemerintahan yang baik di Daerah Istimewa Yogyakarta adalah seperti yang dijelaskan oleh Suwarno (1994: 172) mengenai wara-wara yang dikeluarkan oleh Sri Sultan Hamengkubuwono ke IX yang dimuat dalam Maklumat tanggal 19 September yang berisi nasehat-nasehat yang dituangkan dalam tulisan yang berjudul "Kautaman Niti Priksa Garbane Dewe" (Keutamaan Mawas Diri) yang berisi ajaran tentang arti kemerdekaan, berani mengakui kesalahan pribadi, menjunjung tinggi keutamaan masyarakat berdasarkan semboyan "sayuk rukun, sepi ing pamrih rame ing gawe" (rukun, bekerja keras tanpa pamrih). Semestinya masih ada nilai-nilai kearifan lokal lainnya yang berasal dari Keraton Yogyakarta.

Untuk itu diadakan penelitian dan kajian tentang nilai-nilai kearifan lokal yang berasal dari Keraton Yogyakarta yang dapat dikembangkan menjadi asas-asas umum pemerintahan yang baik di Pemerintah DIY. Penelitian ini dipandang urgen mengingat dalam melaksanakan tugas, peran, dan tanggung jawabnya sebagai pelayanan publik, alat administrasi negara atau alat birokrasi yang ada di Daerah Istimewa Yogyakarta memerlukan kekuasaan/ wewenang yang besar dan potensial untuk disalahgunakan (detournement de pouvuir), digunakan dengan sewenangwenang (abus de droit/willekuer), dan bahkan digunakan bertentangan dengan hukum. Itulah sebabnya diperlukan adanya asas-asas umum pemerintahan yang baik dalam Hukum Administrasi Negara di Indonesia untuk mengatur birokrasi negara menjalankan tugas dan wewenangnya. Asas-asas umum pemerintahan ini bisa dikembangkan berdasarkan nilai-nilai kearifan lokal yang ada di dalam masyarakat.

Kajian ini merupakan hasil penelitian yang merupakan penelitian payung yang menaungi dua penelitian skripsi mahasiswa yang meneliti tentang nilai-nilai kearifan lokal yang bisa dikembangkan ke dalam asas-asas umum pemerintahan yang baik di pemerintah daerah yang ada di DIY. Dua penelitian mahasiswa tersebut meneliti asas-asas umum pemerintahan yang baik di Kabupaten Sleman dan 
asas-asas umum pemerintahan yang baik di Kota Yogyakarta yang juga melihat pengembangan nilai-nilai lokal Keraton Yogyakarta di Kabupaten Sleman dan Kota Yogyakarta. Kajian yang diangkat adalah pengembangan nilai kearfian lokal Keraton Yogyakarta di Pemerintah Daerah Istimewa Yogyakarta. Adapun permasalahan yang diangkat dalam tulisan ini adalah apa nilai-nilai kearifan lokal dari Keraton Yogyakarta yang bisa dipakai untuk mengembangkan asasasas pemerintahan yang baik di DIY? Dan apa nilai-nilai kearifan lokal Keraton Yogyakarta yang telah dituangkan dalam produk-produk hukum DIY?

Untuk mengkaji permasalahan tersebut perlu dipahami dan dikaji dulu beberapa konsep pokok terkait dengan kearifan lokal dan nilai-nilai moral Jawa. Kearifan berasal dari kata "arif". Dalam Kamus Besar Bahasa Indonesia dijelaskan, arif memiliki dua arti, yaitu tahu atau mengetahui. Arti kedua cerdik, pandai dan bijaksana. Kata arif yang jika ditambah awalan "ke" dan akhiran "an" menjadi kearifan yang berarti kebijaksanaan, kecendekiawan sebagai sesuatu yang dibutuhkan dalam berinteraksi, termasuk dalam melayani orang orang lain. Cendekiawan adalah orang yang mempunyai sifat ilmu yaitu netral, jujur dan tidak mempunyai kepentingan antara, melainkan semata-mata didasarkan atas nilai-nilai budaya dan kebenaran sesuai ruang lingkupnya. Kata "lokal", mempunyai arti tempat atau pada suatu tempat atau pada suatu tempat tumbuh, terdapat, hidup sesuatu yang mungkin berbeda dengan tempat lain atau terdapat di suatu tempat yang bernilai yang mungkin berlaku setempat atau mungkin juga berlaku universal (Fahmal, 2006: 30-31). Sedyawati (2007: 381-382) menyatakan bahwa dalam bentangan Indonesia baru dewasa ini, maka yang dimaksud dengan kebudayaan "lokal" mestinya lebih tepat disebut kebudayaan "subbangsa" atau "suku-bangsa". Memang pada umumnya suatu suku bangsa (golongan etnik) itu mempunyai suatu "tanah asal" tertentu di Indonesia, yang bisa meliputi wilayah yang kecil sampai ke wilayah yang sangat luas, atau yang "bercabang-cabang". Kearifan lokal diartikan sebagai "kearifan dalam kebudayaan tradisional" suku-suku bangsa. Kearifan dalam arti luas tidak hanya berupa norma-norma dan nilainilai budaya, melainkan juga segala unsur gagasan, termasuk yang berimplikasi pada teknologi, penanganan kesehatan, dan estetika. Dengan pengertian tersebut maka yang termasuk sebagai penjabaran "kearifan lokal" adalah berbagai pola tindakan dan hasil budaya materialnya. Dalam arti yang luas "kearifan lokal" itu terjabar dalam seluruh warisan budaya, baik yang tangible maupun yang intangible.

Nasiwan (2012: 159) mengemukakan bahwa wacana seputar local wisdom atau kearifan lokal, biasanya selalu disandingkan dengan wacana perubahan, modernisasi, dan relevansinya. Hal ini bisa dimaklumi sebab wacana di seputar kearifan lokal pada prinsipnya berangkat dari asumsi yang mendasar bahwa, nilainilai asli, ekspresi-ekspresi kebudayaan asli dalam konteks geografis dan kultural dituntut untuk mampu mengekspresikan dirinya di tengah-tengah perubahan. Pada sisi lain ekspresi kearifan lokal tersebut juga dituntut untuk mampu merespons perubahan-perubahan nilai dan masyarakat. Kearifan lokal itu tidak akan hilang dari peredaran nilai sebuah masyarakat. Kearifan lokal didefinisikan sebagai kebijaksanaan atau nilai-nilai luhur yang terkandung dalam kekayaankekayaan budaya lokal seperti tradisi, petatah-petitih dan semboyan hidup. 
Mengutip pendapat Wales (dalam Nasiwan, 2012: 16) bahwa kearifan lokal dapat dilihat dari dua perspektif yang saling bertolak belakang, yaitu: extreme acculturation yang memperlihatkan bentuk-bentuk tiruan suatu budaya yang tanpa adanya proses evolusi budaya dan akhirnya memusnahkan bentuk-bentuk budaya tradisional, dan a less extreme acculturation yakni proses akulturasi yang masih menyisakan dan memperlihatkan local genius yaitu adanya unsur-unsur atau ciri-ciri tradisional yang mampu bertahan dan bahkan memiliki kemampuan untuk mengakomodasikan unsur-unsur budaya dari luar serta mengintegrasikannya dalam kebudayaan asli.

Nilai kearifan lokal dapat dikembangkan dalam pelaksanaan pemerintahan sebagai asas-asas umum pemerintahan yang baik. Fahmal (2006: 31) mengutip pendapat Laica Marzuki mengemukakan bahwa di dalam kaidahkaidah hukum (rechtnormen) dibangun nilai-nilai etika hukum (values of legal ethic) yang nilai kepatuhannya didasarkan pada kesadaran hukum (kesadaran hukum pada hakikatnya adalah pematuhan nilai-nilai etika hukum). Manan (dalam Fahmal, 2006: 32) menyatakan bahwa asas hukum bukanlah sebuah norma hukum sebagaimana hukum yang telah dirumuskan dalam berbagai ketentuan perundang-undangan yang serta merta mengikat. Akan tetapi, sebagai penanaman normatif (legal term) bagi nilai etika hukum yang sesungguhnya adalah nilai yang tumbuh dalam budaya hukum masyarakat, sehingga nilai tersebut ditaati sebagai tolok ukur terwujudnya keadilan yang sesungguhnya.

Sementara itu, Asshiddiqie (2011: 5) menyatakan bahwa budaya hukum masyarakat menjadi sangat penting disamping perilaku penegak hukum. Di samping itu, Manan (2004: 5) menyatakan bahwa manusia juga diatur dan tunduk pada aturan adat-istiadat (hukum kebiasaan), hukum agama (sepanjang belum menjadi hukum positif), dan hukum moral.

Penelitian Suwarno (1994: 79-80), menemukan bahwa penanaman unsurunsur tradisional yang berkembang di dalam Keraton (Yogyakarta) telah dilakukan Sultan Hamengku Buwono IX. Sultan memadukan unsur-unsur pemerintahan tradisional yang masih berkembang di dalam Keraton dan unsur birokrasi modern. Sultan Hamengku Buwono VIII mengajarkan ajaran Asthabrata kepada Sultan Hamengku Buwono IX dan memberi pesan agar kelak jika Sultan Hamengku Buwono IX mendapat anugerah kedudukan raja jangan menyombongkan diri karena kedudukannya dan memiliki pendidikan tinggi di Negeri Belanda. Nilainilai tradisional yang di kandung oleh Asthabrata yang tersimpan di Keraton Yogyakarta itu menjadi salah satu dasar pemikiran dan tindakan Sultan Hamengku Buwono IX untuk mengadakan perubahan birokrasi di Yogyakarta.

Pemikiran lain yaitu pemikiran tentang kehidupan bermasyarakat orang Jawa. Kehidupan bermasyarakat orang Jawa sesuai dengan sifat Dewa Baruna dalam Asthabrata, yaitu mengalahkan kepentingan pribadi untuk kepentingan orang banyak dengan dasar cinta sesama. Sultan Hamengku Buwono IX menekankan bahwa hanya orang yang mempunyai wewenang untuk memerintahlah yang harus ditaati. Sultan Hamengku Buwono IX menyatakan bahwa birokrasi pemerintahan merupakan perpaduan antara unsur tradisional dan unsur baru untuk melayani kepentingan rakyat.

Suwarno (1994: 87) juga mengamati pemikiran Sultan Hamengku Buwono IX tentang birokrasi modern dan pemerintahan berdasarkan tradisi, dan 
berpendapat bahwa hal itu menandakan bahwa Sultan mempunyai kemampuan tinggi untuk memadukan kedua pemikiran itu, kemudian mewujudkannya dalam kenyataan. Perwujudan ini juga menuntut kemampuan untuk menyesuaikan pemikiran dan kehendak semua pihak terutama rakyat banyak atau istilah Jawa: $N g u d i$ jumbuhing kawula gusti (mengusahakan kesesuaian antara rakyat dan raja). Suseno (1985: 113) menjelaskan bahwa dalam paham kekuasaan Jawa tertanam motivasi-motivasi kuat bagi penguasa untuk berusaha menjadi seorang penguasa yang baik, yang adil, dan dicintai rakyatnya, yang mempertahankan negaranya dalam keadaan tenteram dan sejahtera.

\section{METODE}

Penelitian yang dilakukan ini termasuk dalam penelitian hukum dengan pendekatan yuridis dan pendekatan budaya yang mengkaji dan menganalisis berbagai nilai-nilai kearifan lokal utamanya yang berasal dari Keraton Yogyakarta dan nilai-nilai kearifan lokal masyarakat Jawa pada umumnya. Nilai-nilai kearifan lokal ini telah dikembangkan menjadi asas-asas umum pemerintahan yang baik dalam produk-produk hukum Pemerintah DIY yang harus dipatuhi dan dipakai sebagai pedoman oleh alat administrasi negara baik pejabat maupun staff di Pemerintah DIY.

Lokasi penelitian adalah Keraton Yogyakarta dan Kantor Pemda DIY khususnya di Biro Hukum Pemda DIY dan Dinas Kebudayaan DIY karena di instansi tersebut dapat digali bahanbahan penelitian yang terkait dengan pengembangan nilai-nilai kearifan lokal dari Keraton Yogyakarta ke dalam produk-produk hukum DIY. Adapun objek penelitian adalah produk-produk hukum Pemda DIY, arsip-arsip Keraton Yogyakarta dan dokumen-dokumen lain yang memuat nilai-nilai kearifan lokal Keraton Yogyakarta. Subjek penelitian adalah Kepala Biro Hukum Pemda DIY dan Kepala Seksi Pelestarian Budaya Dinas Kebudayaan Pemda DIY. Di samping itu, subjek penelitian ini adalah salah seorang pengageng Keraton Yogyakarta yang mengetahui tentang nilai-nilai kearifan lokal Keraton Yogyakarta dan kearifan lokal masyarakat Jawa yang telah dianut oleh masyarakat Yogyakarta dan dikembangkan dalam asas-asas umum pemerintahan yang baik di Pemerintah Daerah Istimewa Yogyakarta.

Pengumpulan data dilakukan dengan teknik wawancara dan dokumentasi. Analisis data dilakukan melalui tahaptahap reduksi data, unitisasi/kategorisasi data, dan penafsiran data.

\section{HASIL DAN PEMBAHASAN Local Wisdom terkait dengan Pengem- bangan AUPB di DIY}

Tidak bisa dipungkiri bahwa sampai saat ini keraton masih merupakan pusat kebudayaan, khususnya kebudayaan Jawa. Selain sebagai pusat kebudayaan Jawa, keraton juga sebagai pusat etika, estetika, filsafat dan bermacam-macam adat. Sebagai pusat kebudayaan, nilainilai keraton sering dipakai sebagai acuan oleh masyarakat (khususnya masyarakat DIY) dalam pengembangan kebudayaan mereka. Dari keratonlah mengalir nilainilai dan simbol ke bawah paling deras. Makna kata budaya Jawa pada umumnya dan budaya Daerah Istimewa Yogyakarta pada khususnya adalah nilai-nilai luhur (value), keyakinan-keyakinan (beliefs), ideologi atau anggapan (assumption) yang digunakan sebagai rencana atau pedoman perilaku dari generasi ke generasi di kalangan masyarakat Jawa pada umumnya dan Daerah Istimewa Yogyakarta pada khususnya. 
Nilai diartikan sebagai ukuran yang harus ditegakkan untuk melestarikan irama kehidupan sesuai dengan kodrat alam dan cita-cita luhut suatu komunitas masyarakat dan bangsa. Keyakinan diartikan sebagai sesuatu yang diterima sebagai hal yang benar atau salah (right or wrong) dan tidak perlu diperdebatkan, dan yang terakhir asumsi adalah sesuatu yang diterima sebagaimana adanya tanpa disadari (taken for granted) dan tidak perlu dibuktikan. Ada banyak sekali nilai-nilai, keyakinan-keyakinan dan asumsi-asumsi yang dipergunakan oleh masyarakat di sekitar Keraton Yogyakarta sebagai pedoman perilaku dalam memecahkan masalah. Beberapa ungkapan budaya Jawa yang sarat dengan makna dan selaras dengan karakteristik masyarakat Yogyakarta adalah sebagai berikut.

Manunggaling Kawula Gusti, merupakan prinsip tentang kepemimpinan dari Keraton Yogyakarta yang berpihak kepada rakyat. Pemimpin berasal dari rakyat dan harus mengabdikan diri hanya untuk kepentingan rakyat.

Berbudi Bawa Leksana Ambeg Adil Para Marta, dalam pandangan Jawa, seorang raja harus memiliki watak berbudi bawa leksana ambeg adil para marta yang artinya kurang lebih adalah selalu memberikan keadilan kepada segenap rakyat. Melalui kepemimpinannya segenap rakyat dipuaskan karena menerima keadilan. Berkaitan dengan itu, seorang raja haruslah seorang yang gung binathara yaitu adil, berwatak mulia, pembela rakyat, dan pelindung rakyat. Ciri kepemimpinan seperti yang digambarkan di atas harus ditegakkan dan menjadi dasar evaluasi integritas.

Sabda Pandhita Ratu Tan Kena Wola-wali, salah satu ciri kearifan yang berasal dari Keraton adalah sabda pandhita ratu tan kena wola-wali, yang memiliki arti seorang pemimpin harus memiliki komitmen. Yang sudah dikatakan harus dilakukan. Perkataannya tidak berubah-ubah, plin-plan, tidak jelas, apalagi dusta.

Keutamaan Integritas, seorang pemimpin harus memiliki integritas yang sangat tinggi. Dalam serat Nitipraja dikatakan bahwa: lamun sira tinitah nrepati, wonten ta kecaping nitipraja, nista madya utamane, nista reke jentan wruh, ing durgama mungsuhe prapti, katungkul ing pangulah, dan-reksa ing ayun, ajrih kang kalungsura, jenengipun gara-gara babo wani, asanggup ing ayunan. Artinya adalah, "jika kamu ditakdirkan menjadi raja, ada nasihat dalam Nitipraja, yang nista, sedang, dan utama. Nista jika tidak paham, hingga musuh datang, terlalu bersuka ria, diselimuti oleh nafsu, berjiwa penakut terhadap orang, namanya gara-gara itu, dikuasai nafsu pribadi". Sudah seharusnya jika di dalam pemerintahan tercipta kewibawaan, dan bersih. Nilainilai kearifan lokal yang ditegakkan dan yang benar-benar dipraktikkan akan membersihkan pemerintahan dari segala praktik korupsi, kolusi, dan nepotisme.

Pemimpin Harus Peka oleh Kritik, dalam kearifan Jawa, seorang pemimpin tidak imun terhadap kritik. Bahkan semakin tinggi level kepemimpinan seseorang maka semakin tinggi kepekaannya terhadap kritik. Prinsip itu terlihat terlihat dari ungkapan dupak bujang, esem bupati, sasmita narendra. Bujang adalah buruh atau pelayan yang berperadaban rendah dan berpikiran dangkal. Untuk menasihatinya, kita harus memberi teguran yang keras, harfiah, dan langsung. Pada level bupati, dia akan lebih peka, hanya dengan senyuman (esem) ia sudah sadar diri dan menangkap hal-hal yang bersifat simbolik (sasmita). Seorang 
pemimpin harus peka dengan apa menjadi aspirasi rakyatnya.

Spiritual Quotient (SQ). Seorang pemimpin Jawa adalah wakil Tuhan di muka bumi, sehingga Sultan mempunyai gelar Kalifatullah. Seorang yang menjadi pemimpin harus mendapat visi dan karunia dari Tuhan, disebut pulung, wahyu, atau ndaru. Hal ini menunjukkan kedekatan seorang pemimpin dengan Tuhan, dan memiliki kedalaman kehidupan rohani. Spiritualitas yang membawa pemimpin untuk bisa menghargai pluralitas dan multikulturalitas, sehingga ia dapat menjadi pengayom bagi masyarakat yang jamak.

Di samping hal-hal di atas, ditemukan pula nilai-nilai kearifan lokal yang seharusnya diwujudkan dalam watak kepemimpinan berdasarkan ajaran $\mathrm{Ki}$ Hajar Dewantoro dan falsafah Jawa yang berlaku di Keraton Yogyakarta. Ajaran dari Ki Hajar Dewantara (Suwarno, 1994), yaitu:

Ing ngarsa sung tuladha. Ing ngarso itu didepan /dimuka, sun berasal dari kata ingsun yang artinya saya, tuladha berarti tauladan. Jadi makna ing ngarso sun tuladha adalah menjadi seorang pemimpin harus mampu memberikan suri tauladan bagi orang-orang di sekitarnya, sehingga yang harus dipegang teguh oleh seseorang adalah kata suri tauladan.

Ing madya mangun karsa. Ing madya artinya di tengah-tengah, mangun berarti membangkitan atau menggugah dan karso diartikan sebagai bentuk kemauan atau niat. Dapat disimpulkan bahwa seseorang di tengah kesibukannya harus juga mampu membangkitkan atau menggugah semangat. Karena itu seseorang juga harus mampu memberikan inovasi-inovasi di lingkungannya dengan menciptakan suasana yang lebih kondusif untuk keamanan dan kenyamanan.
Tut wuri handayani. Tut wuri artinya mengikuti dari belakang dan handayani berati memberikan dorongan moral atau dorongan semangat. Tut wuri handayani mempunyai makna bahwa seseorang harus memberikan dorongan moral dan semangat kerja dari belakang.

Falsafah Jawa yang berlaku di Keraton Yogyakarta, yaitu: Hamangku, Hamengku, dan Hamengkoni. Falsafah Hamangku, mengandung makna mengangkat harkat dan martabat masyarakat dalam berbagai aspek kehidupan dengan pengabdian tanpa pamrih. Membesarkan hati, dengan lebih banyak memberi daripada menerima. Hakikat dari berbudi bawa leksana itulah aktualisasi dari Hamangku. Falsafah Hamengku, mengandung makna hangrengkuh atau ngemong, melindungi dan mengayomi secara adil, tanpa membeda-bedakan golongan, keyakinan, dan agama. Hamengku identik dengan hambeg adil paramarta. Falsafah Hamengkoni. Falsafah mengandung makna keteladanan dan watak gung binathara. Yakni dalam situasi dan keadaan yang sulit, pemimpin adalah juga pengayom yang berdiri paling depan, menjadi panutan dan tampil mengambil tanggung jawab dengan segala resikonya. Apabila sifat-sifat kepemimpinan ini dilandasi dengan falsafah Sawiji, Greget, Sengguh, Ora Mingkuh dan dijiwai dengan idealisme yang kuat, komitmen yang tinggi, integritas moral, serta nurani yang bersih disertai dengan semangat Golong-Gilig, maka lengkaplah sebutan Wataking Satriya Ngayogyakarta.

Falsafah-falsafah atau nilai-nilai lokal (local wisdom) dari Keraton Yogyakarta inilah yang dapat mendasari prinsipprinsip tata kelola pemerintahan di kabupaten/kota, utamanya di DIY. Nilainilai kearifan lokal di DIY sesuai dengan karakter dan sifat masyarakat Provinsi Daerah Istimewa Yogyakarta. 


\section{Penuangan Nilai-nilai Kearifan Lokal Keraton Yogyakarta dalam Produk Hukum di DIY}

Sampai saat ini kepala pemerintahan Daerah Istimewa Yogyakarta masih dipegang oleh seorang Gubernur yang berasal dari Raja Keraton Yogyakarta yang sudah berlangsung secara turun temurun. Banyak nilai-nilai dari Keraton Yogyakarta yang bisa dikembangkan menjadi bagian dari asas-asas umum pemerintahan yang baik di Pemerintah Daerah Istimewa Yogyakarta yang kemudian dituangkan dalam produkproduk hukum pemerintahan di Daerah Istimewa Yogyakarta.

Keberadaan Keraton Yogyakarta sebagai simbol budaya Jawa sekaligus sebagai pusat kebudayaan Jawa di Yogyakarta mempunyai nilai lebih terhadap proses pertumbuhan kebudayaan di DIY. Keraton Yogyakarta juga disimbolkan sebagai sumber nilai historis dan filosofis yang dipercaya sangat berpengaruh terhadap perilaku masyarakat serta pemimpinnya (pemerintah).

Sebagai suatu wilayah yang menjadi bagian dari Negara Indonesia yang di dalamnya terdapat sebuah kerajaan yang secara historis banyak memiliki nilainilai kearifan lokal sudah seharusnya Pemerintah Daerah Istimewa Yogyakarta menuangkan nilai-nilai kearifan lokal dari Keraton Yogyakarta tersebut ke dalam produk-produk hukum daerah. Produk hukum daerah yang dimaksud di sini adalah produk hukum yang terkait dengan tata pemerintahan di Daerah Istimewa Yogyakarta. Setelah ditelusuri dan dikaji Pemerintah Daerah Istimewa Yogyakarta telah menuangkan nilai-nilai kearifan lokal dalam dua produk hukum yang terkait dengan pelaksanaan tata pemerintahan di DIY. Dua produk hukum tersebut adalah Peraturan Gubernur
Daerah Istimewa Yogyakarta Nomor 72 Tahun 2008 tentang Budaya Pemerintahan SATRIYA dan Peraturan Daerah Provinsi Daerah Istimewa Yogyakarta Nomor 4 Tahun 2011 tentang Tata Nilai Budaya Yogyakarta.

Peraturan Gubernur Nomor 72 Tahun 2008 tentang Budaya Pemerintahan SATRIYA merupakan penjabaran dari nilai kearifan lokal Hamemayu Hayuning Bawono. Hal ini tercantum pada bagian menimbang huruf (b) yang menyatakan bahwa Daerah Istimewa Yogyakarta memiliki kekhasan budaya dengan nilai filosofi Hamemayu Hayuning Bawono dan ajaran moral Sawiji, Greget, Sengguh, Ora Mingkuh dan semangat Golonggilig. Selanjutnya pada bagian huruf (c) dinyatakan bahwa kekhasan budaya tersebut sebagaimana dimaksudkan butir b perlu dimiliki oleh setiap aparatur di DIY. Maksud adanya peraturan ini adalah dijadikanya Peraturan Gubernur Nomor 72 Tahun 2008 tentang Budaya Pemerintahan SATRIYA sebagai pedoman untuk melaksanakan budaya pemerintahan yang telah ditetapkan peraturan gubernur tersebut. Tujuan dari ditetapkannya peraturan ini adalah untuk meningkatkan efisiensi, efektivitas, transparansi, dan akuntabilitas dalam pelaksanaan tugas aparat pemerintahan di Darah Istimewa Yogyakarta.

Budaya pemerintahan SATRIYA merupakan penjabaran dari nilai kearifan lokal salah satunya adalah Hamemayu Hayuning Bawono. SATRIYA mempunyai dua makna sebagai berikut.

Pertama, sebagai watak ksatria yang artinya di dalam menjalankan tugasnya seorang aparatur negara memegang teguh nilai-nilai Sawiji, Greget, Sengguh,Ora Mingkuh, dan semangat Golong-gilig. Sawiji dapat diartikan sebagai seorang aparatur negara yang selalu mempunyai 
konsentrasi dalam setiap tindakan yang ia lakukan. Hal ini berguna untuk menunjang kinerja pegawai pemerintah bahwa setiap tindakan haruslah fokus dan yakin. Greget yang mempunyai makna bahwa dalam bekerja haruslah mempunyai semangat yang tinggi untuk mencapai visi dan misi yang telah ditetapkan bersama. Sengguh merupakan ajaran bahwa di dalam bekerja seorang aparatur negara harus percaya diri dengan tindakan yang telah ia lakukan. Ora Mingkuh yang mempunyai arti dalam bekerja seorang abdi negara harus memiliki sifat tanggung jawab yang tinggi.

Kedua, SATRIYA sebagai singkatan dari Selaras, Akal budi, Teladan, Rela Melayani, Inovatif, Yakin, dan Percaya diri. Makna dari Selaras ialah dalam kehidupan selalu menjaga keseimbangan, dan kelestarian hubungan antara alam dan Tuhan Yang Maha Esa dan sesama manusia hal tersebut dapat dinyatakan melalui perilaku takwa kepada Tuhan Yang Maha Esa, mencintai lingkungan hidup menjaga dan melestarikan, dan menjaga hubungan yang harmonis antara manusia dengan manusia seperti teman, keluarga, rekan kerja, dan masyarakat. Akal Budi mempunyai makna keseluruhan jati diri seseorang merupakan pengejawantahan peri kemanusiaannya atau dalam artian bahwa akal budi merupakan cerminan watak pribadi seseorang. Hal ini bisa dijiwai melalui sifat sadar akan rasa benar dan salah, jujur, taat pada norma, taat etika, dan mampu menerima keadaan dengan baik (adaptif). Teladan ialah sifat seseorang yang dapat dijadikan contoh oleh lingkungan sekitarnya dengan cara menjalankan peranannya di dalam masyarakat dengan adil, arif bijaksana sebagai upaya untuk memajukan kehidupan masyarakat. Rela melayani yaitu bahwa setiap pegawai pemerintah dituntut mampu melayani dengan baik. Adapun indikatornya adalah seorang pegawai bisa menempatkan kepentingan masyarakat terlebih dahulu daripada kepentingan kelompok atau pribadi. Inovatif ialah seorang pegawai pemerintah dapat melakukan pembaharuan yang bersifat positif kearah kemajuan dengan cara selalu belajar untuk memperoleh pembaharuan, dan berkemauan keras mencari, menciptakan sesuatu yang baru menuju kemajuan. Yakin dan percaya diri seorang aparatur negara dalam mekasanakan tugasnya selalu didasari keyakinan dan percaya diri bahwa apa yang dilaksanakan akan membawa kemajuan bagi masyarakat.

Dari penjelasan tersebut dapat dikatakan bahwa nilai kearifan lokal Hamemayu Hayuning Bawana adalah salah satu nilai yang mengedepankan dan mengajarkan perbuatan yang seimbang antara manusia dengan manuisa dan manusia dengan Tuhannya. Selain itu dalam Peraturan Gubernur tersebut dijelaskan bahwa nilai Haememayu Hayuning Bawana dapat dijadikan sebagai ilham untuk mewujudkan pemerintahan yang baik dan bersih.

Adanya Peraturan Gubernur Nomor 72 Tahun 2008 tentang Budaya Pemerintahan SATRIYA merupakan sebuah pedoman agar aparat Pemerintah Daerah Istimewa Yogyakarta bisa menjadikannya pedoman dan menerapkan melayani masyarakat di Daerah Istimewa Yogyakarta. Bahkan diharapkan Peraturan Gubernur ini juga merupakan wujud pelestarian, penghormatan budaya yang dilakukan oleh Pemerintah Provinsi Daerah Istimewa Yogyakarta.

Peraturan Daerah Istimewa Yogyakarta Nomor 4 Tahun 2011 tentang Tata Nilai Budaya Yogyakarta dikeluarkan oleh 
Pemerintah Daerah Istimewa Yogyakarta dengan dilatarbelakangi oleh beberapa hal sebagai berikut.

Pertama, dalam memahami aktivitas manusia sebagai makhluk sosio-kultural diperlukan pemahaman sistem atau konfigurasi nilai-nilai yang melandasi cara berpikir, cara berekspresi, cara berperilaku, dan hasil tindakan manusia yang pada dasarnya bukan hanya sekadar reaksi spontan atas situasi objektif yang menggejala di sekitarnya, melainkan jauh lebih dalam dikerangkai oleh suatu sistem atau tata nilai tertentu yang berlaku dalam suatu kebudayaan.

Kedua, manusia pada hakikatnya bukan hanya produk kebudayaan, tetapi juga pencipta kebudayaan yang dapat merancang suatu strategi kebudayaan bagi masa depannya, menuju kehidupan bersama yang lebih berkeadaban.

Ketiga, tata nilai budaya Yogyakarta merupakan kekayaan daerah tidak berwujud (intangible) yang tak ternilai sehingga perlu dilestarikan, dikembangkan, dan dilindungi dengan peraturan daerah.

Keempat, proses globalisasi dapat mengakibatkan pergeseran tata nilai budaya, tidak terkecuali tata nilai budaya Yogyakarta.

Kelima, Undang-Undang Dasar Negara Republik Indonesia Tahun 1945 memberi jaminan serta amanat kepada setiap orang untuk menjaga, melestarikan serta mengimplementasikan tata nilai budaya lokal yang tumbuh dan berkembang di masyarakat.

Dengan dikeluarkannya Peraturan Daerah Istimewa Yogyakarta Nomor 4 Tahun 2011 tentang Tata Nilai Budaya Yogyakarta diharapkan masyarakat DIY dapat melestarikan nilai-nilai budaya Jawa dalam setiap aspek kehidupan bermasyarakat. Berdasarkan ketentuan Pasal 3 Peraturan Daerah Provinsi
Daerah Istimewa Yogyakarta Nomor 4 Tahun 2011 tentang Tata Nilai Budaya Yogyakarta, Tata Nilai Budaya Yogyakarta bertujuan sebagai: (a) pedoman pelaksana bagi setiap warga masyarakat dalam bertingkah laku dan dalam melaksanakan pembangunan di daerah, (b)pedoman pelaksana bagi Pemerintah DIY dan Pemerintah Kabupaten/Kota untuk melaksanakan tugas pokok dan fungsinya dalam melaksanakan pembangunan di daerah, dan (c) acuan pembentukan produk hukum daerah.

Di dalam ketentuan Pasal 4 Peraturan Daerah Provinsi Daerah Istimewa Yogyakarta Nomor 4 Tahun 2011 dinyatakan bahwa tata nilai budaya Yogyakarta meliputi tata nilai: religio-spriritual, moral, kemasyarakatan, adat dan tradisi, pendidikan dan pengetahuan, teknologi, penataan ruang dan arsitektur, mata pencaharian, kesenian, bahasa, benda cagar budaya; dan kepemimpinan dan pemerintahan.

Masing-masing tata nilai tersebut dijelaskan dan dijabarkan secara rinci dalam ketentuan Pasal 4 Peraturan Daerah Istimewa Yogyakarta Nomor 4 Tahun 2011 tentang Tata Nilai Budaya Yogyakarta. Di dalam penjabaran mengenai tata nilai kepemimpinan dinyatakan bahwa dalam hidup bersama, sekumpulan manusia membutuhkan pemimpin. Seorang pemimpin dituntut memiliki kelebihan dibanding yang dipimpin baik dalam hal pengetahuan, keberanian, maupun kearifan. Seorang pemimpin harus berani tampil di depan memberi teladan bagi yang dipimpin (ing ngarsa sung tuladha), seorang pemimpin harus mampu menggugah semangat atau memotivasi yang dipimpin (ing madya mangun karsa) agar lebih giat dalam perjuangan hidup, dan memberi dorongan, kekuatan, dan perlindungan (ing wuntat tut wuri handayani) agar yang dipimpin kian 
percaya diri dan senantiasa memperoleh kemajuan dalam menapaki kehidupan.

\section{SIMPULAN}

Setelah melihat uraian pada bagianbagian tulisan terdahulu, maka dapat dikemukakan simpulan sebagai berikut. Pertama, nilai-nilai kearifan lokal (local wisdom) Keraton Yogyakarta bisa dipakai untuk mengembangkan asas-asas pemerintahan yang baik di DIY yang di antaranya adalah nilai: Hamemayu Hayuning Bawana, Sawiji Greget Sengguh Ora Mingkuh, dan Golong-gilig. Kedua, nilai-nilai kearifan lokal (local wisdom) Keraton Yogyakarta yang telah dituangkan dalam produk-produk hukum di DIY yang dominan adalah nilai selaras, akal budi, teladan, rela melayani, inovatif, yakin dan percaya diri. Nilai-nilai itu merupakan penjabaran dari nilai Hamemayu Hayuning Bawana, Sawiji Greget Sengguh Ora Mingkuh, dan Golong-gilig. Nilai-nilai tersebut dituangkan dalam produk hukum yang berbentuk Peraturan Gubernur Daerah Istimewa Yogyakarta Nomor 72 Tahun 2008 tentang Budaya Pemerintahan SATRIYA dan Peraturan Daerah Provinsi Daerah Istimewa Yogyakarta Nomor 4 Tahun 2011 tentang Tata Nilai Budaya Yogyakarta.

Berdasarkan simpulan di atas dapat diajukan saran-saran sebagai berikut. Seyogyanya Pemerintah Daerah yang ada di DIY menderivasikan asas-asas umum pemerintahan yang baik dalam produkproduk hukum baik berupa peraturan daerah, peraturan gubernur, peraturan bupati, peraturan walikota, dan peraturan- peraturan lainnya yang merupakan produk hukum daerah terutama peraturanperaturan yang mengikat alat administrasi negara di daerah. Seyogyanya asas-asas umum pemerintahan yang baik yang harusnya diverifikasi pada produk-produk hukum daerah terutama di DIY juga dikembangkan dari nilai-nilai lokal yang berkembang di daerah yang bersangkutan.

\section{DAFTAR PUSTAKA}

Asshiddqie, J. 2011. Perihal UndangUndang. Jakarta: Rajawali Pers.

Fahmal, M. 2006. Peran Asas-Asas Umum Pemerintah yang Layak dalam Mewujudkan Pemerintahan yang Bersih. 2006. Yogyakarta: UII Press.

Manan, B. 2004. Hukum Positif Indonesia. Yogyakarta: FH UII Press.

Nasiwan. 2012. Menuju Indigenousasi Ilmu Sosial Indonesia. Yogyakarta: FISTRANS Institute.

Peraturan Daerah Provinsi Daerah Istimewa Yogyakarta Nomor 4 Tahun 2011 tentang Tata Nilai Budaya Yogyakarta.

Peraturan Gubernur Nomor 72 Tahun 2008 Tentang Budaya Pemerintahan SATRIYA.

Sedyawati, E. 2007. Keindonesiaan dalam Budaya. Jakarta: Wedatama Widya Sastra.

Suseno, F. M. 1985. Etika Jawa Sebuah Analisa Falsafi tentang Kebijaksanaan Hidup Jawa. Jakarta: PT Gramedia.

Suwarno. 1994. Hamengku Buwono IX dan Sistem Birokrasi Pemerintahan Yogyakarta 1942-1974. Yogyakarta: Kanisius. 